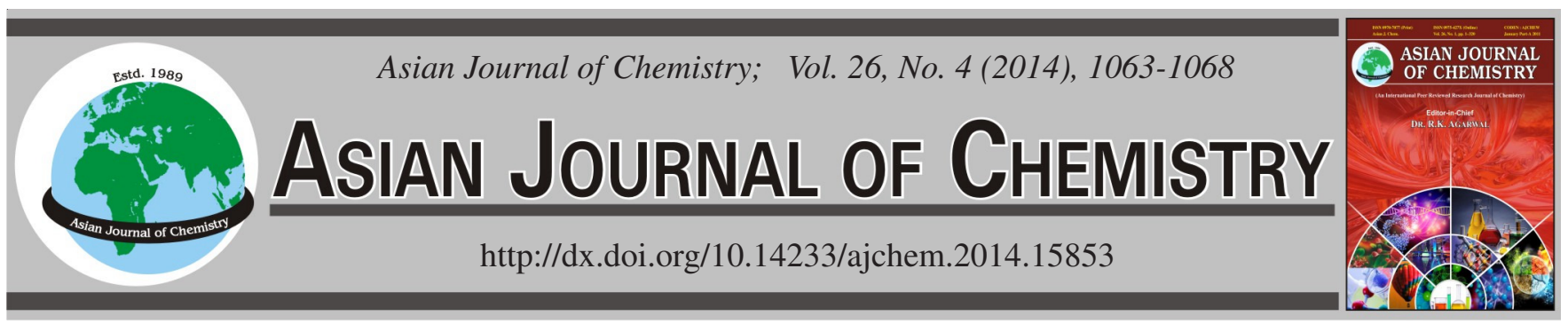

\title{
Assessment of Selected Heavy Metals Uptake from Soil by Vegetation of Two Areas of District Attock, Pakistan
}

\section{Mehwish Bashir ${ }^{1}$, Sofia Khalid ${ }^{1, *}$, Umer Rashid $^{2, *}$, Muhammad Adrees $^{3}$, Muhammad Ibrahim $^{3}$ and Md. Saiful Islam ${ }^{4}$}

\begin{abstract}
${ }^{1}$ Department of Environmental Sciences, Fatima Jinnah Women University, Rawalpindi, Pakistan ${ }^{2}$ Institute of Advanced Technology, Universiti Putra Malaysia, 43400 UPM Serdang, Selangor, Malaysia

${ }^{3}$ Department of Environmental Sciences, Government College University, Faisalabad-38000, Pakistan

${ }^{4}$ Department of Chemistry, Universiti Putra Malaysia, 43400 UPM Serdang, Selangor, Malaysia
\end{abstract}

*Corresponding authors: E-mail: sofiarahim@ hotmail.com; umer.rashid@yahoo.com

\begin{abstract}
The present study was conducted to examine the heavy metals in the soil and vegetation of two areas of district Attock (Pakistan). Investigations were made to compare the heavy metals concentrations $(\mathrm{Cu}, \mathrm{Pb}, \mathrm{Cd}, \mathrm{Ni}, \mathrm{Zn}$ ) in a relatively less polluted site (Khour City) and a polluted site (Khour Company). An assessment of the selected heavy metals uptake by the soil and vegetation was made through calculation of bioaccumulation and enrichment factors. Samples of soil and plants were collected from both sites. From each site, four points were selected randomly for vegetation and soil sampling. Plant species included Eucalyptus camaldulensis, Calotropis procera, Ziziphus nummularia, Cynodon dactylon, Acacia senegal, Parthenium hysterophorus, Dalbergia sissoo and Desmostachya bipinnata. Heavy metals were detected in soil and vegetation of both areas using atomic absorption spectrophotometer. Lead concentration was highest amongst other heavy metals in both soil and vegetation (Cynodon dactylon). In studied plant species heavy metals concentrations varied among different species. The level of heavy metal concentration in Khour Company was greater compared to Khour City. The increasing level of heavy metal contamination in the Khour Company area may be because of higher traffic density and industrialization compared to Khour City.
\end{abstract}

Keywords: Heavy metal uptake, Pollution, Pakistan, Vegetation.

\section{INTRODUCTION}

The animal and plant health is usually associated with exposures to metals that cause toxic effects to these living organisms. According to an estimate by World Health Organization' a total of 3700 children die daily due to water borne diseases owing to various factors (pathogens and metals) ${ }^{1}$. As far as plants are concerned, they have been considered valuable to alleviate the heavy metals and pesticides from contaminated soils. Plants have been used in three mechanisms i.e., phytoextraction, rhizo-filtration and phyto-stabilization to eliminate and stabilize the metals from soil and water as well ${ }^{2}$. The metals are very important elements because these are part of food chain and act as essential nutrients. Trace metals on the other hand are essential when present in lower concentrations and are toxic when present in large concentrations above the permissible limits ${ }^{3}$. The bio-accumulation of metals may be as a consequence of continuous exposure and may cause diseases typical to heavy metals ${ }^{4}$.

Soil, in larger perspective, acts as a sink and also as a source of pollution having inherent capacity to transfer pollutants to groundwater and/or food chain and then to the human and/or animals ${ }^{5,6}$. Belonging to non-renewable natural resource category, soil is the foundation of human's survival and development ${ }^{7}$. It is considered as fundamental part of environment and acts as natural buffer to control the movement of different elements between different spheres ${ }^{8}$. Hence, it is very important to protect this important natural resource for sustainable use and production for future generations. The soil is being deteriorated in terms of quality and productivity due to increased use of chemicals (e.g. agro-chemicals, products of rapid industrialization) as reported by different researchers $^{9,10}$. The heavy metals may be mobilized or immobilized by the change of environmental conditions such as agricultural inputs in the form of fertilizers, pesticides, land use, etc.

Soil-plant-animal continuum is the predominant pathway of heavy metal intake especially in the agricultural areas ${ }^{11}$. Heavy metal pollution is considered a result of anthropogenic activities $^{12}$. During the recent past, the effects of urbanization and industrialization on heavy metal accumulation in soils and their distribution have been discussed ${ }^{2,13}$. This undesirable 
change in physical, chemical and biological characteristics reduce the amount of land for cultivation and habitation ${ }^{10}$. The chemical nature of soil is derived from the type of weathered rock (parent material of that area). This ultimately controls the translocation of heavy metals through the food. The excessive metal intake (through the consumption of contaminated vegetables and other plant parts) may be associated with different human health risks ${ }^{14}$.

Heavy metals are defined as metallic chemical element that has relatively high density and toxicity even at low concentrations. Heavy metal pollution has been described as an important environmental problem because these are nonbiodegradable and accumulate in water, soil, sediments and living organism ${ }^{5,7}$. These are present in the earth crust naturally ${ }^{15}$. Some amount of heavy metal is needed for metabolism in human but when its concentration reaches to high level then it is toxic to living organisms. According to Singh and Agrawal ${ }^{16}$ the main sources of heavy metal pollution are fossil fuel combustion, mining, municipal waste, agricultural chemicals like fertilizer etc. Heavy metals cause deleterious effect on plants except those plants which are tolerant to heavy metals and survive even in the presence of heavy metals ${ }^{17}$. Heavy metal accumulation in plants has been reported to cause the wilting of leaves, reduction in plant height, inactivation of enzyme system, decrease in root and shoot length and slow physiological processes such as respiration, photosynthesis, etc. ${ }^{18}$.

As far as literature is concern, no previous research work was done in the study area. However, the present study enables us to investigate the trace and heavy metal contamination caused by both the pedogenic and anthropogenic sources. Efforts were also done to examine the heavy metals in soil and vegetation in two areas of district Attock.

\section{EXPERIMENTAL}

Study area: Khour is a town of Tehsil Pindigheb, District Attock. Khour is divided into two parts; Khour Company and Khour City (will be abbreviated as K. Company and K. City, respectively). In K. Company, Pakistan Oilfield Limited (POL) has been working for many years. There are many pollution sources in K. Company compared to K. City, which is less populated. The major source of pollution in $\mathrm{K}$. Company is heavy traffic because of petrol pump. The petrol pump supplies diesel, petrol and CNG. The shops in the petrol pump are tyre shops and vehicular maintenance shops. Samples of roadside soil and vegetation were collected from both parts of Khour to compare the level of heavy metal pollution.

Sampling of soil and vegetation: The roadside area of K. Company and K. City were selected for the present investigation. Soil and vegetation samples were collected from each of the two studied areas in spring season of 2012. Eight studied species included Eucalyptus camaldulensis, Calotropis procera, Zizyphus nummularia, Cynodon dactylon, Acacia senegal, Parthenium hysterophorus, Dalbergia sissoo and Desmostachya bipinnata. The roadside area was divided into three zones for sampling of soil and vegetation. Each zone was $400 \mathrm{~m}$ long. Two replicates of each studied plant species were selected from each zone. Soil samples were collected by diging at the depth of $15 \mathrm{~cm}$. Twelve soil samples were collected from both studied sites, stored in polyethylene bag and brought to the Environmental Sciences Laboratory for further analysis. Identification of plant species was carried out by consulting Floras and final confirmation from Taxonomist. The physio-chemical characteristics of soil of the area Khour are presented in Fig. 1.

Heavy metal analysis: Leaf samples were washed with distilled water, air dried and were put into oven for $24 \mathrm{~h}$ at $70{ }^{\circ} \mathrm{C}$. After oven drying, the leaf samples were ground into fine powder in a grinder. Ground material was then passed through sieves to get homogeneous material. After sieving,

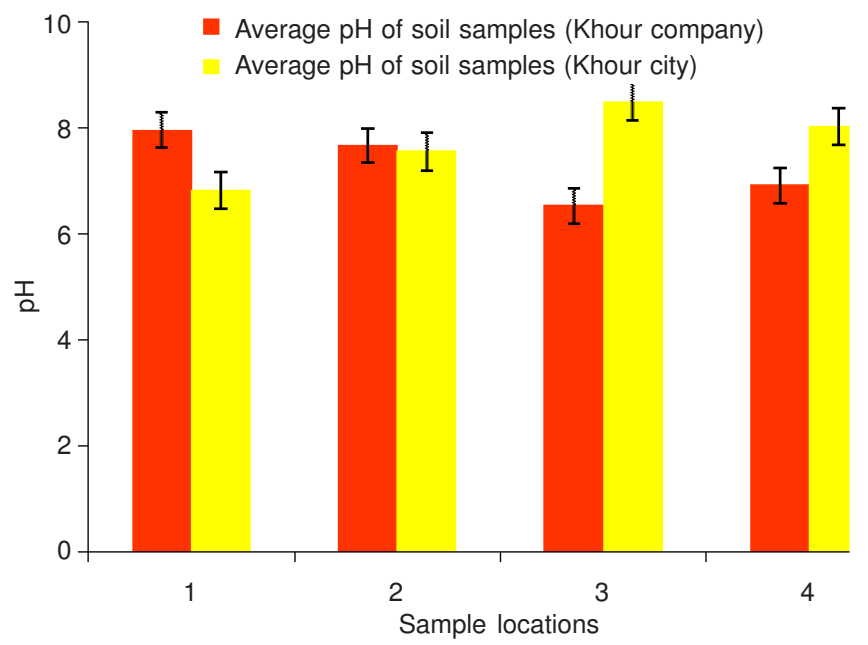

(a) $\mathrm{pH}$ in soil samples

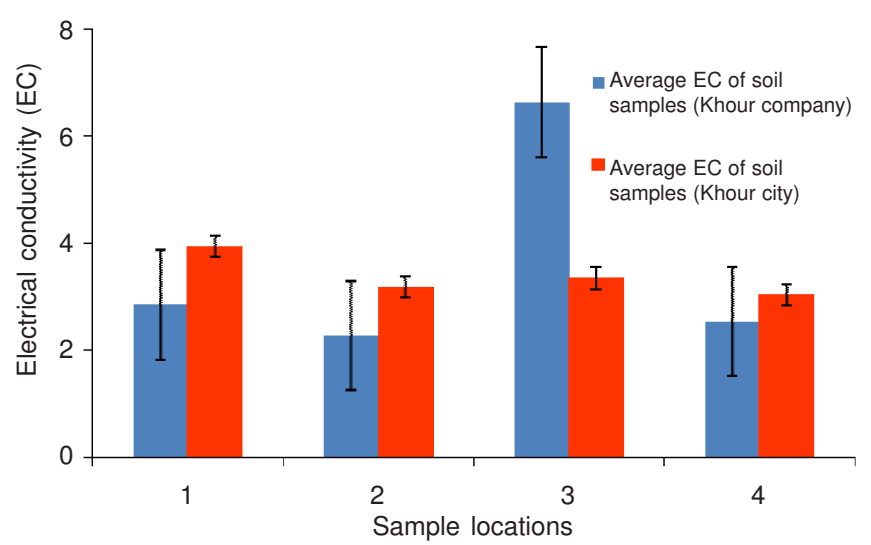

(b) Electrical conductivity (EC) in soil samples

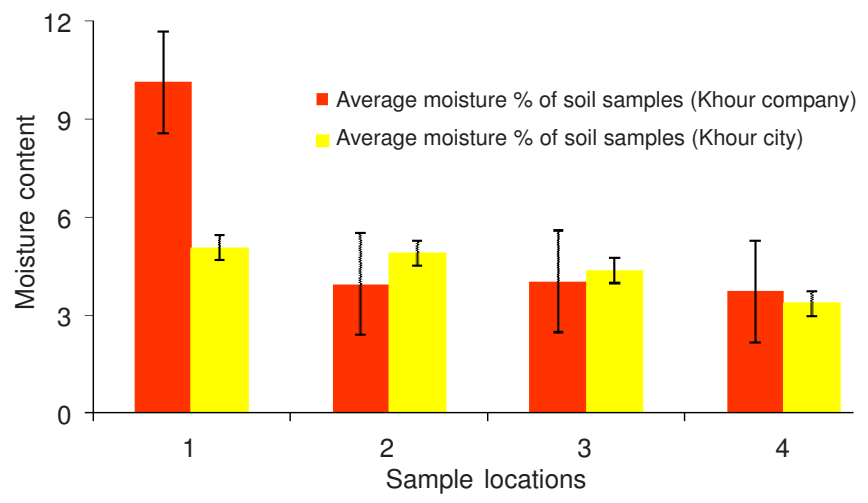

(c) Moisture content in (\%) soil samples 


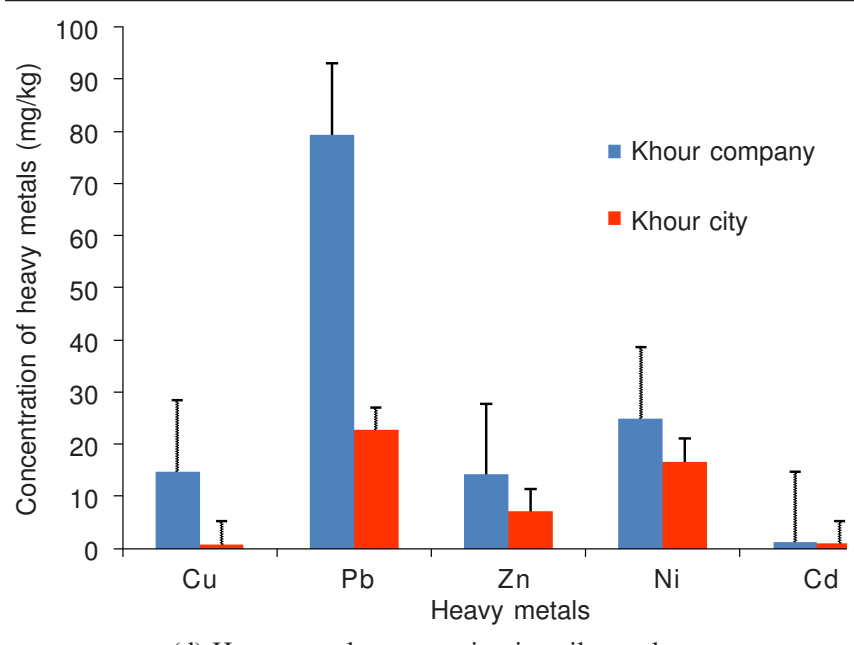

(d) Heavy metal concentarion in soil samples

Fig. 1. Physio-chemical parameters and heavy metals analysis of soil from Khour

$1 \mathrm{~g}$ of each sample was measured and $2 \mathrm{~mL}$ of $\mathrm{H}_{2} \mathrm{SO}_{4}$ was added and incubated for $24 \mathrm{~h}$ at room temperature. The material was heated on hot plate in a fume hood. After heating, hydrogen peroxide was added until the complete material was colourless. Distilled water was added in colourless material to make the volume up to $50 \mathrm{~mL}$. Soil samples were ground into fine powder by the use of pestle and mortar. The ground material was sieved by $2 \mathrm{~mm}$ sieve. One gram of soil was digested by aqua regia $\left(3: 1 \mathrm{HNO}_{3}: \mathrm{HCl}\right)$. After cooling the digested samples, $10 \mathrm{~mL}$ distilled water was added. Samples were filtered and distilled water was added to make the total volume $50 \mathrm{~mL}$. Analysis of soil and vegetation samples was carried out by atomic absorption spectrophotometer (Spectra 220).

Measurements of bioaccumulation and enrichment factors: Bioaccumulation factor has been defined as ratio of concentration of metals in plants to the concentration of metals in soil. This give an idea about the ability of the plant to accumulate the metals with respect to soil metals concentration. Enrichment factor on the other hand is the degree of heavy metals accumulation in plants and soil on contaminated site with respect to soil and plant on non-contaminated site ${ }^{16}$.

Physio-chemical analysis: Three physiochemical parameters were determined which included $\mathrm{pH}, \mathrm{EC}$ (electrical conductivity) and moisture content. Portable $\mathrm{pH}$ (WTW Series ino Lab pH 720) and EC meter (Jenway model 470 portable conductivity/TDS meter) was used for $\mathrm{pH}$ and EC measurement. Moisture content was determined according to Rayan ${ }^{19}$. The same is presented in Fig. 1.

\section{RESULTS AND DISCUSSION}

In K. Company the concentration of heavy metals pollution was greater compared to K. city. The $\mathrm{pH}$ in K. Compnay ranged between 6.0 and 7.9, while in $\mathrm{K}$. City the $\mathrm{pH}$ range was from 6.8 to 8.76 (Fig. 1). Electrical conductivity of soil from $\mathrm{K}$. Company ranged between 2.27 and $2.53 \mu \mathrm{S} \mathrm{cm}^{-1}$, while in $\mathrm{K}$. city it ranged from 3.03 to $3.93 \mu \mathrm{S} \mathrm{cm}$. The average content of moisture in K. Company ranged between 3.73 and 10.13 while in K. city it ranged between 3.39 and 5.06. In soil samples, the average concentration of heavy metals found in K. Company ranged from 1.11 to 79.46 while in K. city the concentration of heavy metals ranged from $0.82-22.74 \mathrm{mg} \mathrm{Kg}^{-1}$ (Fig. 1). The level of $\mathrm{Pb}$ in $\mathrm{K}$. Company was highest and $\mathrm{Cd}$ was lowest than other heavy metals.

All studied plant species showed different metal absorption ranges. Enrichment factor tells about the availability of metals and can be used to check the distribution and availability of heavy metals between a contaminated and non-contaminated site $^{16}$. When the value of enrichment factor $>1$ then it means the availability and distribution of heavy metals is greater in contaminated site. Vegetation growing at the contaminated sites generally showed greater metals accumulation ${ }^{15}$. All of the studied soil samples in the present investigation revealed enrichment factor $>1$. Soil heavy metals concentration found in Khour Company was in the order of $\mathrm{Cd}<\mathrm{Zn}<\mathrm{Cu}<\mathrm{Ni}<$ $\mathrm{Pb}$, whereas in K. City it was in the order of $\mathrm{Cd}<\mathrm{Cu}<\mathrm{Zn}<$ $\mathrm{Ni}<\mathrm{Pb}$ (Fig. 2).

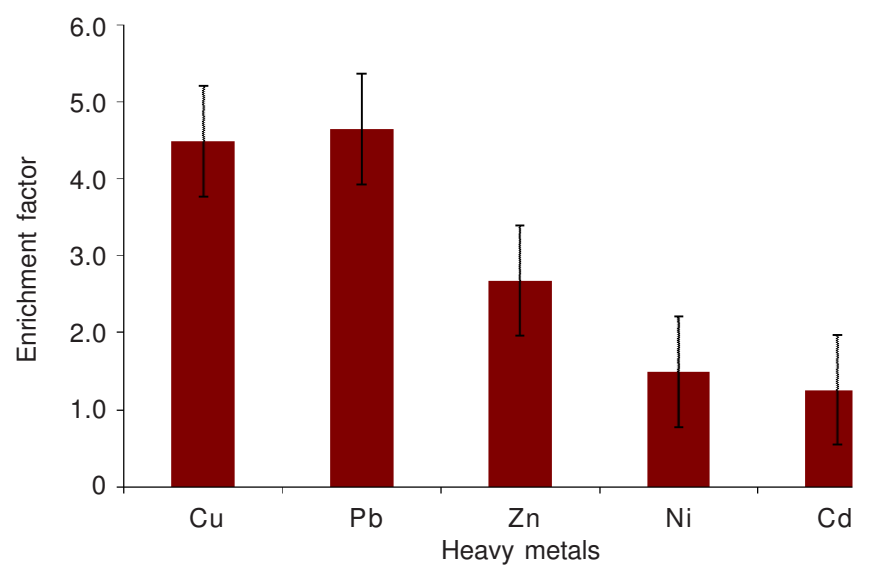

(a) Enrichment factor for soil from Khour

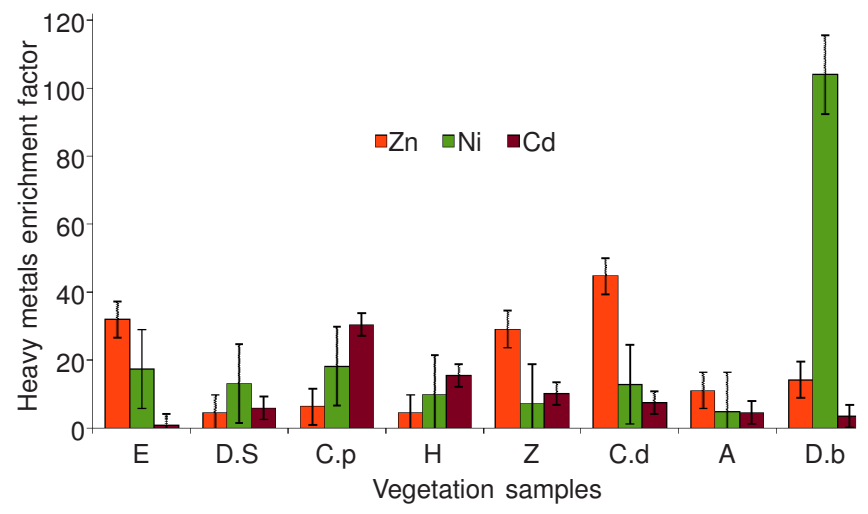

(b) Enrichment factor for vegetation from Khour

Fig. 2. Enrichment factor of soil and vegetation from Khour

In Khour city, the order of heavy metals concentration for studied plant species was as follows; Eucalyptus camaldulensis $\mathrm{Cd}<\mathrm{Ni}<\mathrm{Zn}<\mathrm{Cu}<\mathrm{Pb}$, Calotropis procera $\mathrm{Cd}<\mathrm{Zn}(=\mathrm{Ni})<$ $\mathrm{Cu}<\mathrm{Pb}$, Ziziphus nummularia $\mathrm{Cd}<\mathrm{Zn}<\mathrm{Cu}<\mathrm{Ni}<\mathrm{Pb}$, Cynodon dactylon $\mathrm{Zn}<\mathrm{Cd}<\mathrm{Ni}<\mathrm{Cu}<\mathrm{Pb}$, Dalbergia sissoo $\mathrm{Cd}<\mathrm{Ni}<\mathrm{Zn}<\mathrm{Cu}<\mathrm{Pb}$, Desmostachya bipinnata $\mathrm{Ni}<\mathrm{Zn}<$ $\mathrm{Cd}<\mathrm{Cu}<\mathrm{Pb}$, Parthenium hysterophorus $\mathrm{Cd}<\mathrm{Ni}<\mathrm{Cu}<\mathrm{Zn}$ $<\mathrm{Pb}$. While, in Khour Company the order of heavy metals concentration found for various plants was as follows; Eucalyptus camaldulensis $\mathrm{Cd}<\mathrm{Cu}<\mathrm{Ni}<\mathrm{Pb}<\mathrm{Zn}$, Calatropis procera $\mathrm{Cu}<\mathrm{Zn}<\mathrm{CD}<\mathrm{Ni}<\mathrm{Pb}$, Ziziphus nummularia $\mathrm{Cu}<\mathrm{Cd}<\mathrm{Ni}$ $<\mathrm{Zn}<\mathrm{Pb}$, Cynodon dactylon $\mathrm{Cu}<\mathrm{Cd}<\mathrm{Ni}<\mathrm{Zn}<\mathrm{Pb}$, Acacia 
senegal $\mathrm{Cd}<\mathrm{Cu}<\mathrm{Zn}<\mathrm{Ni}<\mathrm{Pb}$, Dalbergia sissoo $\mathrm{Cu}<\mathrm{Cd}<$ $\mathrm{Zn}<\mathrm{Ni}<\mathrm{Pb}$, Desmostachya bipinnata $\mathrm{Cd}<\mathrm{Cu}<\mathrm{Zn}<\mathrm{Ni}<$ $\mathrm{Pb}$ and for Parthenium hysterophorus $\mathrm{Cd}<\mathrm{Cu}<\mathrm{Ni}<\mathrm{Zn}<$ $\mathrm{Pb}$. All of the studied vegetation was found to be good indicator for determination of heavy metals.

Bioaccumulation factor (BAF) tells about the accumulation of metals. If the value of $\mathrm{BAF}<1$ or $\mathrm{BAF}=1$ then it means that plants do not accumulate the metals rather they only absorb the metals. If the value of BAF $>1$ then it means that plants accumulate the metals. For K. Company the order of bioaccumulation factor determined for various plants was as follows; Calotopis procera $\mathrm{Cu}<\mathrm{Pb}<\mathrm{Ni}<\mathrm{Zn}<\mathrm{Cd}$, Eucalyptus camaldulensis $\mathrm{Cu}<\mathrm{Pb}<\mathrm{Ni}<\mathrm{Cd}<\mathrm{Zn}$, Ziziphus nummularia $\mathrm{Cu}<\mathrm{Ni}<\mathrm{Pb}<\mathrm{Zn}<\mathrm{Cd}$, Cynodon dactylon $\mathrm{Cu}<$ $\mathrm{Zn}<\mathrm{Ni}<\mathrm{Pb}<\mathrm{Cd}$, Acacia senegal $\mathrm{Cu}<\mathrm{Pb}<\mathrm{Zn}<\mathrm{Ni}<\mathrm{Cd}$, Dalbergia sissoo $\mathrm{Cu}<\mathrm{Pb}<\mathrm{Ni}<\mathrm{Zn}<\mathrm{Cd}$, Desmostachya bipinnata $\mathrm{Cu}<\mathrm{Pb}<\mathrm{Ni}<\mathrm{Zn}<\mathrm{Cd}$, Parthenium hysterophorus $\mathrm{Pb}<\mathrm{Ni}<\mathrm{Cu}<\mathrm{Zn}<\mathrm{Cd}$.

Instead of $\mathrm{Pb}$ in Parthenium hysterophorus and $\mathrm{Cu}$ in Dalbergia sissoo, the value of BAF $<1$ was found. In Khour city, the BAF of heavy metals for studied plant species was in the order Eucalyptus camaldulensis $\mathrm{Ni}<\mathrm{Zn}<\mathrm{Cu}<\mathrm{Cd}<\mathrm{Pb}$, Calatropis procera $\mathrm{Ni}<\mathrm{Zn}<\mathrm{Cd}<\mathrm{Pb}<\mathrm{Cu}$, Ziziphus nummularia $\mathrm{Zn}<\mathrm{Ni}<\mathrm{Cu}<\mathrm{Pb}<\mathrm{Cd}$, Cynodon dactylon $\mathrm{Zn}<$ $\mathrm{Ni}<\mathrm{Pb}<\mathrm{Cu}<\mathrm{Cd}$, Acacia senegal $\mathrm{Zn}<\mathrm{Ni}<\mathrm{Pb}<\mathrm{Cu}<\mathrm{Cd}$, Dalbergia sissoo $\mathrm{Ni}<\mathrm{Zn}<\mathrm{Cu}<\mathrm{Cd}<\mathrm{Pb}$, Desmostachya bipinnata $\mathrm{Zn}<\mathrm{Ni}<\mathrm{Cu}<\mathrm{Pb}<\mathrm{Cd}$, Parthenium hysterophorus $\mathrm{Zn}<\mathrm{Cd}<\mathrm{Ni}<\mathrm{Pb}<\mathrm{Cu}$. The BAF $<1$ for $\mathrm{Zn}, \mathrm{Ni}$ in Eucalyptus camaldulensis, $\mathrm{Cu}, \mathrm{Zn}, \mathrm{Ni}$, in Calatropis procera, $\mathrm{Zn}, \mathrm{Ni}$ in Ziziphus nummularia, $\mathrm{Zn}$, Ni for Cynodon dactylon, $\mathrm{Zn}$ for Acacia senegal, Ni for Parthenium hysterophorus, $\mathrm{Zn}$ for Desmostachya bipinnata. The BAF $<1$ for $\mathrm{Zn}$, Ni in Eucalyptus camaldulensis, $\mathrm{Cu}, \mathrm{Zn}, \mathrm{Ni}$, in Calatropis procera, $\mathrm{Zn}, \mathrm{Ni}$ in Ziziphus nummularia, $\mathrm{Zn}$, Ni for Cynodon dactylon, $\mathrm{Zn}$ for Acacia senegal, Ni for Parthenium hysterophorus, $\mathrm{Zn}$ for Desmostachya bipinnata. Soleimani et al. ${ }^{20}$ reported that Cynodon dactylon is the accumulator of heavy metals because it grows quickly and is involved in soil stabilization. Cynodon dactylon is the major accumulator of heavy metals. The accumulation of metals depends on the availability of metals, $\mathrm{pH}$ of soil and the root system of plants. When the root system is extensive and $\mathrm{pH}$ is alkaline then plants accumulate more metals. In Cynodon dactylon root system and growth is extensive. It has greater ability to survive in both saline and non saline environment. Parthenium hysterophorus has less capacity to absorb the heavy metals because of poor root system. Calotopis procera has more capacity to accumulate the heavy metals because of its large surface area of leaves. Kovacs ${ }^{21}$ mentioned that the broad leaves show greater metals accumulation because of large exposed surface area.

Plants with deep root system accumulate greater heavy metals. Eucalyptus camaldulensis, Ziziphus nummularia, Acacia senegal and Dalbergia sissoo have deep root system so they accumulate the heavy metals ${ }^{4,10,15}$. It was reported by many researchers that the accumulation of heavy metals also depends on different survival strategies $e . g$., the tolerance of different species towards environmental stresses. Grasses have more resistance; produce greater biomass and soil stabilization. The grasses therefore show more absorption of heavy metals.
Desmostachya bipinnata studied in the present work is also a grass having long leaves and greater biomass production ${ }^{22}$. Tangahu et $a .^{22}$ mentioned that besides morphological characters certain other factors are also very important for heavy metals accumulation. These factors are the availability of metals ion, chelating agents, environmental conditions, root zone and the growth rate (Fig. 3).

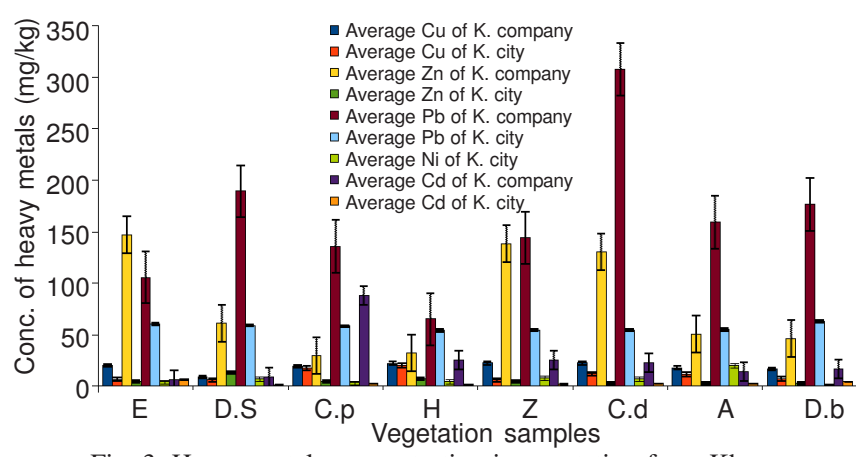

Fig. 3. Heavy metals concentration in vegetation from Khour

In Khour city concentration of $\mathrm{Pb}$ was found to be higher compared to other heavy metals. The reason might be traffic density and application of fertilizer to crops. In K. city, Dalbergia sissoo showed greater concentration of heavy metals compared to other species and this may be because it is also one of the greater biomass producing species. The concentration of heavy metals uptake also depends on the distance from the roadside. The distance of Desmostachya bipinnata from road was greater as compared to other vegetation in the $\mathrm{K}$. city. So, the concentration of heavy metals in Desmostachya bipinnata was lower than other species in K. city. The soil moisture content is an important factor for hyper-accumulation of metals. When soil moisture level increases hyper-accumulator plants grow rapidly and they accumulate more metals ${ }^{18}$. The average moisture content in the present study was in the order Khour Company $>$ Khour city and this might be one of the reasons for greater uptake of metals in Khour Company (Fig. 4). The $t$-test showed significant difference in the metal concentration in soil samples and for vegetation samples between two studied sites (Tables 1-5). The uptake of metals by roots and the transfer to shoot and aerial parts of plants also depends on various soil physico-chemical properties including organic matter, metal concentrations etc. ${ }^{23}$.

TABLE-1

$t$-TEST RESULTS FOR SOIL HEAVY METALS CONTAMINATION AT $95 \%$ CONFIDENCE INTERVAL

\begin{tabular}{cccc}
\hline Heavy metals & Khour company & Khour city & Significance \\
\hline $\mathrm{Cu}$ & $14.79 \pm 8.64$ & $0.82 \pm 0.49$ & $* *$ \\
$\mathrm{Ni}$ & $24.85 \pm 2.17$ & $16.63 \pm 1.3$ & $* * *$ \\
$\mathrm{Zn}$ & $14.11 \pm 1.5$ & $7.01 \pm 1.2$ & $* * *$ \\
$\mathrm{~Pb}$ & $79.46 \pm 45.7$ & $22.74 \pm 4.12$ & $*$ \\
$\mathrm{Cd}$ & $1.1 \pm 0.1$ & $0.88 \pm 0.05$ & $*$ \\
\hline
\end{tabular}

$* p<0.05,{ }^{* *} p<0.01, * * * p<0.001$. The values are means $\pm \mathrm{SD}$, where $\mathrm{SD}=$ standard deviation.

\section{Conclusion}

It is concluded from this study, that all of the studied vegetation have capacity to absorb the heavy metal. The concentrations of different metals vary in different type of 
TABLE-2

$t$-TEST RESULTS OF TWO SPP. FOR HEAVY METALS CONTAMINATION AT $95 \%$ CONFIDENCE INTERVAL

\begin{tabular}{cccc|ccc}
\hline \multirow{2}{*}{ Heavy metals } & \multicolumn{3}{c}{ Eucalyptus camaldulensis } & \multicolumn{3}{c}{ Dalbergia sissoo } \\
\cline { 2 - 7 } & Khour company & Khour city & Significance & Khour company & Khour city & Significance \\
$\mathrm{Cu}$ & $20.4 \pm 5.45$ & $6.89 \pm 1.12$ & $* *$ & $9.1 \pm 5.04$ & $6.86 \pm 1.12$ & $*$ \\
$\mathrm{Ni}$ & $75.82 \pm 5.5$ & $4.37 \pm 0.22$ & $* * *$ & $94.95 \pm 3.21$ & $7.23 \pm 7.04$ & $* * *$ \\
$\mathrm{Zn}$ & $147 \pm 4.25$ & $4.6 \pm 0.09$ & $* * *$ & $61.1 \pm 4.25$ & $13.67 \pm 18.03$ & $* *$ \\
$\mathrm{~Pb}$ & $105.5 \pm 26.1$ & $60.27 \pm 5.53$ & $* *$ & $189.4 \pm 22.41$ & $60.27 \pm 5.53$ & $* * *$ \\
$\mathrm{Cd}$ & $6.57 \pm 1.16$ & $6.89 \pm 0.08$ & $* * *$ & $9.38 \pm 0.28$ & $1.58 \pm 0.1$ & $* * *$ \\
\hline$* p<0.05, * * p<0.01, * * * p<0.001$. The values are means $\pm \mathrm{SD}$, where SD $=$ standard deviation.
\end{tabular}

TABLE-3

$t$-TEST RESULTS OF TWO SPP. FOR HEAVY METALS CONTAMINATION AT $95 \%$ CONFIDENCE INTERVAL

\begin{tabular}{cccc|ccc}
\hline \multirow{2}{*}{ Heavy metals } & \multicolumn{3}{c}{ Calatropis procera } & \multicolumn{3}{c}{ Parthenium hysterophorus } \\
\cline { 2 - 7 } & Khour company & Khour city & Significance & Khour company & Khour city & Significance \\
\hline $\mathrm{Cu}$ & $20.10 \pm 3.660$ & $9.30 \pm 1.30$ & $* * *$ & $22.63 \pm 4.05$ & $11.5 \pm 0.36$ & $* *$ \\
$\mathrm{Ni}$ & $66.05 \pm 1.070$ & $7.23 \pm 3.50$ & $* * *$ & $44.89 \pm 2.79$ & $4.50 \pm 0.08$ & $* * *$ \\
$\mathrm{Zn}$ & $30.10 \pm 2.005$ & $4.76 \pm 0.17$ & $* * *$ & $32.24 \pm 1.72$ & $7.10 \pm 0.10$ & $* * *$ \\
$\mathrm{~Pb}$ & $135.81 \pm 4.300$ & $66.00 \pm 58.29$ & $* * *$ & $65.10 \pm 12.16$ & $54.50 \pm 3.90$ & $* *$ \\
$\mathrm{Cd}$ & $87.95 \pm 1.580$ & $2.89 \pm 0.25$ & $* * *$ & $25.30 \pm 0.87$ & $1.63 \pm 0.08$ & $* * *$ \\
\hline$* * p<0.01, * * * p<0.001$. The values are means $\pm \mathrm{SD}$, where $\mathrm{SD}=$ standard deviation.
\end{tabular}

TABLE-4

$t$-TEST RESULTS OF TWO SPP. FOR HEAVY METALS CONTAMINATION AT $95 \%$ CONFIDENCE INTERVAL

\begin{tabular}{|c|c|c|c|c|c|c|}
\hline \multirow{2}{*}{ Heavy metals } & \multicolumn{3}{|c|}{ Ziziphus nummularia } & \multicolumn{3}{|c|}{ Cynodon dactylon } \\
\hline & Khour company & Khour city & Significance & Khour company & Khour city & Significance \\
\hline $\mathrm{Cu}$ & $22.63 \pm 0.50$ & $6.25 \pm 0.07$ & $* * *$ & $22.7 \pm 0.61$ & $12.20 \pm 1.20$ & $* * *$ \\
\hline $\mathrm{Ni}$ & $56.50 \pm 3.30$ & $7.90 \pm 0.40$ & $* * *$ & $95.9 \pm 19.90$ & $7.50 \pm 2.90$ & $* * *$ \\
\hline $\mathrm{Zn}$ & $138.60 \pm 5.08$ & $4.70 \pm 0.08$ & $* * *$ & $130.4 \pm 6.70$ & $2.90 \pm 0.30$ & $* * *$ \\
\hline $\mathrm{Pb}$ & $144.00 \pm 65.60$ & $54.50 \pm 4.08$ & $*$ & $307.6 \pm 20.10$ & $54.50 \pm 3.90$ & $* * *$ \\
\hline $\mathrm{Cd}$ & $25.60 \pm 1.07$ & $2.50 \pm 0.05$ & $* * *$ & $22.8 \pm 5.02$ & $3.09 \pm 0.09$ & $* * *$ \\
\hline
\end{tabular}

TABLE-5

$t$-TEST RESULTS OF TWO SPP. FOR HEAVY METALS CONTAMINATION AT $95 \%$ CONFIDENCE INTERVAL

\begin{tabular}{|c|c|c|c|c|c|c|}
\hline \multirow{2}{*}{ Heavy metals } & \multicolumn{3}{|c|}{ Acacia senegal } & \multicolumn{3}{|c|}{ Desmostachya bipinnata } \\
\hline & Khour company & Khour city & Significance & Khour company & Khour city & Significance \\
\hline $\mathrm{Cu}$ & $18.18 \pm 0.32$ & $11.58 \pm 0.12$ & $* * *$ & $16.9 \pm 0.40$ & $7.2 \pm 0.15$ & $* * *$ \\
\hline $\mathrm{Ni}$ & $96.40 \pm 5.80$ & $20.10 \pm 10.70$ & $* * *$ & $76.9 \pm 1.05$ & $0.7 \pm 0.02$ & $* * *$ \\
\hline $\mathrm{Zn}$ & $50.60 \pm 0.56$ & $2.97 \pm 0.04$ & $* * *$ & $46.4 \pm 1.50$ & $3.2 \pm 0.12$ & $* * *$ \\
\hline $\mathrm{Pb}$ & $159.20 \pm 1.50$ & $55.30 \pm 3.90$ & $* * *$ & $176.5 \pm 8.50$ & $62.7 \pm 1.61$ & $* * *$ \\
\hline $\mathrm{Cd}$ & $14.20 \pm 0.70$ & $3.13 \pm 0.09$ & $* * *$ & $16.7 \pm 0.20$ & $4.8 \pm 0.10$ & $* * *$ \\
\hline
\end{tabular}

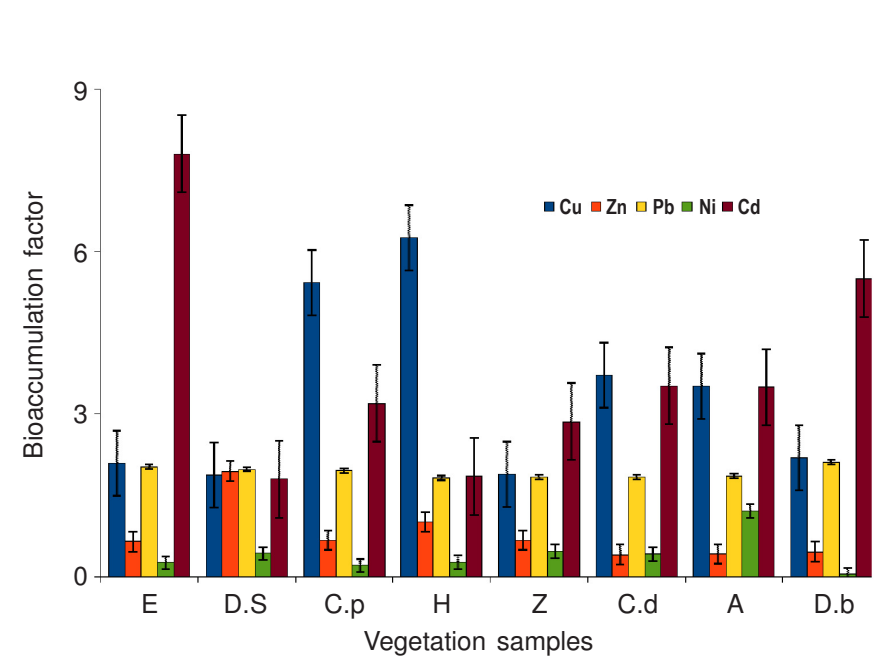

(a) Bio accumulation factor of vegetation from Khour city

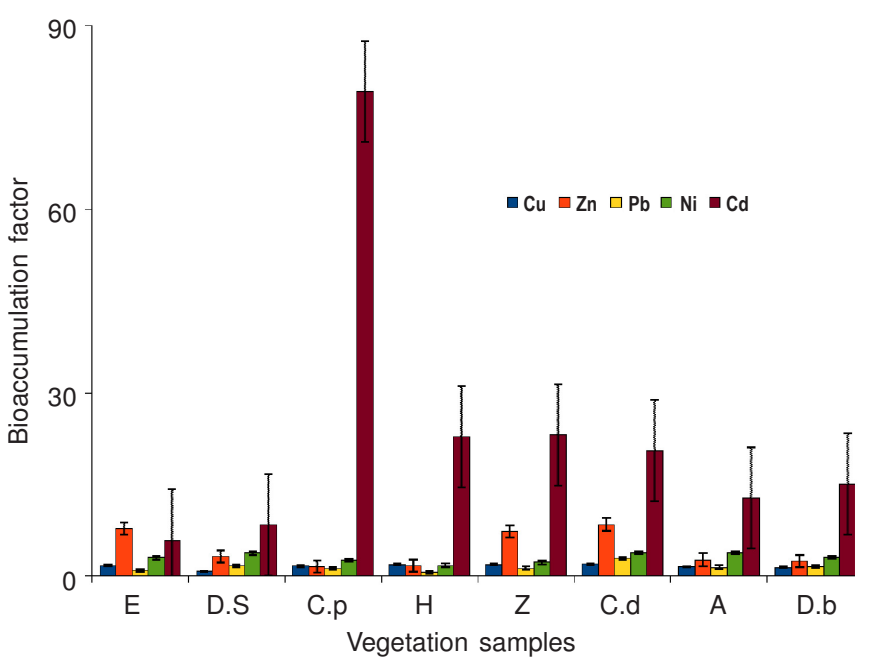

(b) Bio accumulation factor of vegetation from Khour company

Fig. 4. Bioaccumulation factor of vegetation from Khour city and Khour Company 
vegetation. Grasses were the hyper-accumulator of heavy metals. The pollution rate in Khour Company was greater compared to Khour city.

\section{ACKNOWLEDGEMENTS}

This research work was carried out at Fatima Jinnah Women University, Rawalpindi and is part of research thesis. All authors have contributed substantially at different stages of investigations and write up. The authors thank Dr. Mansoor Hameed for help in plant identification.

\section{REFERENCES}

1. WHO, World Health Organization, Study on Environmental Burden of Diseases in Children: Key Findings (Fact sheet EURO/05/04), Copenhagen (2004).

2. K. Ahmad, M. Ibrahim, Z.I. Khan, Y. Rizwan, A. Ejaz, A. Fardsous, S. Gondal, D.J. Lee and M. Al-Yemeni, Saudi J. Biol. Sci., 18, 317 (2011).

3. S.H. Raza, F. Shafiq and M. Tahir, Pak. J. Life Soc. Sci., 11, 8 (2013).

4. V.A. Nguyen, S. Bang, P.H. Viet and K. Kim, Environ. Int., 35, 466 (2009).

5. H. Rehman, A. Ali, A. Tanveer and M. Hussain, Pak. J. Life Soc. Sci., 11, 70 (2013).

6. K. Rehman, S. Ashraf, U. Rashid, M. Ibrahim, S. Hina, T. Iftikhar and S. Ramzan, Pak. J. Bot., 45, 391 (2013).

7. A. Fardous, A.S. Gondal, Z.A. Shah, K. Ahmad, Z.I. Khan, M. Ibrahim, A. Ejaz, W. Ahmad, S. Ullah and E.E. Valeem, Pak. J. Bot., 42, 2411 (2010)
8. M. Ibrahim, K.H. Han, S.K. Ha, Y.S. Zhang and S.O. Hur, Sains Malaysiana, 41, 285 (2012).

9. J. Iqbal and M.H. Shah, J. Hazard. Mater., 192, 887 (2011).

10. K. Ahmad, Z.I. Khan, S. Ashraf, A. Ejaz, M. Shaheen, S.H. Raza, F. Abbas and H.M. Tahir, Pak. J. Life Soc. Sci., 11, 42 (2013).

11. M.A. Sarwar, M. Ibrahim, M. Tahir, K. Ahmad, Z.I. Khan and E.E. Valeem, Pak. J. Bot., 42, 1361 (2010)

12. Y. Al-Zubi, J. Arid Environ., 70, 63 (2007).

13. M. Irfan, U. Rashid, M. Ibrahim, Z. Nisa, A.H. Al-Muhtaseb and S. Ali, Asian J. Chem., 25, 9315 (2013).

14. S. Khan, S. Rehman, A.Z. Khan, M.A. Khan and M.T. Shah, Ecotoxicol. Environ. Saf., 73, 1820 (2010).

15. A. Kabata-Pendias and H. Pendias, Trace Elements in Soils, Boca Raton, London, New York, CRC Press, edn 3 (2001).

16. A. Singh and M. Agrawal, IIOAB J., 2, 22 (2011).

17. N. Khellaf and M. Zerdaoui, Iran. J. Environ. Health Sci., 6, 161 (2009).

18. J. Scott Angle, A.J.M. Baker, S.N. Whiting and R.L. Chaney, Plant Soil, 256, 325 (2003).

19. J. Ryan, G. Estefan and A. Rashid, Soil and Plant Analysis Laboratory Manual, ICARDA (2001).

20. M. Soleimani, M.A. Hajabbasi, M. Afyuni, A.H. Charkhabi and H. Shariatmadari, J. Environ. Sci. (China), 7, 59 (2009).

21. M. Kovacs, in ed.: M. Kovacs, Harbaceous Flowering Plants. In: Biological Indicators in Environmental protection, Ellis Horwood, New York (1992).

22. B.V. Tangahu, S.R.S. Abdullah, H. Basri, M. Idris, N. Anuar and M. Mukhlisin, Int. J. Chem. Eng., Article ID 939161 (2011). 